\title{
A Novel Groundwater Sustainability Index using AHP/GIS Approach
}

\author{
M.Sadek, K.Hagagg* \\ ${ }^{1}$ Egyptian Nuclear and Radiological Regulatory Authority (ENRRA), Cairo, Egypt. \\ *Corresponding Authors: K.Hagagg, Egyptian Nuclear and Radiological Regulatory Authority \\ (ENRRA), Cairo, Egypt.
}

\begin{abstract}
In the context of water scarcity and food deficit while population progressively over-increasing, agricultural expansion into deserts become urgent, this requires sustainable groundwater resources to be secured. A wide range of sustainability indicators are available in literatures but efforts are still needed to develop them into measurable indexes that help to judge the extent to which the groundwater resources are developed sustainably and to direct toward better development
\end{abstract}

This work introduces a novel groundwater sustainability index developed using the Saaty's Analytic Hierarchy Process (AHP) which is a widely used Multi-Criteria Decision Analysis (MCDA) method. Five indicators have been selected in this work (Change in Water level, Renewability of Groundwater, Aquifer Saturated Thickness, Water Quality and Vulnerability Indexes), these consider both quantitative and qualitative dimensions of the resources and reflect the economic and environmental sustainability and social well-being. The selected criteria and sub criteria have been assigned weights and rates based on their relative importance to the main goal, the weights and rates were compared with each other in pair-wise matrixes, the eigen values and consistency ratio were calculated to validate the assigned weights and rates of the selected parameters; the ranges of these parameters are classed and rated then reclassified with GIS and $R S$ for application of the sustainability index in pilot area.

The results of hydrochemical and isotopic analysis of groundwater samples as well as mapping of inventoried data form ElKhatatba pilot area have been used for hydrochemical and hydrogeological characterization of the system and for preparation the site thematic layers on which the developed indexapplied. The overall sustainability of groundwater resources in the ElKhatatba area vary between moderate to poor grades moderate to poor grades which highlights the necessity for continuous monitoring and better management of the groundwater resources. Finally, the proposed index was validated using the change in land use with time

Keywords: Water Resources Sustainability, AHP, Hydrochemical and Isotopic Indicator, Hydrogeological Indicator

\section{INTRODUCTION}

Groundwater resources are considered the key to all human activities and their survival race, particularly in arid regions; development projects depend essentially on the ability to manage these resources and to protect their quality and quantity and utilize them such efficiently. Nowadays, Egypt has limited share of Nile water that is the main source of surface water, and main recharge source for surrounding aquifers, especially after the construction of the Ethiopian Dam (GERD), (Sadek and Hagagg, 2020). The rapid continuous increase in population in Egypt and the continuous development in irrigation projects become imperative to maintain and protect the available groundwater resources and to sustainably develop its use.

Groundwater sustainability which is the subject of this work was defined as the development and use of groundwater in some way to meet the needs of present and future demand without causing unacceptable environmental, economic or social consequences" (Alley et al 1999). It is also defined as 'maintaining long-term, dynamically stable storage [and flow] of high-quality groundwater using inclusive, equitable, and long-term governance and management' (Gleeson et al 2020). The sustainable management of groundwater resources necessitates developing measures or metrics that 
help determining the state of sustainability and to explore the factors and actions necessary to maintain it. Several studies have been initiated to develop indices of water resources sustainability based on a wide scale of indicators available in lieratures, for example, Canadian Watershed Sustainability Index-CWSI (Policy Research Initiative, 2007), Watershed Sustainability Index-WSI (Chaves and Alipaz, 2007), West Java Water Sustainability Index-WJWSI (Juwana et al., 2009), Sustainability Index for Integrated Urban Water Management-SIUWM (De Carvalho et al., 2009).

This work is a devoted to develop a novel groundwater sustainability index for the groundwater in ElKhatatba area, Western Nile fringes, using the Analytic Hierarchy Process (AHP) (Saaty, 1980) as a tool for Multi- Criteria Decision Analysis (MCDA). Five proposed groundwater criteria based on measurable and observable data have been selected for sustainability study in this paper; those criteria are thought to provide information about groundwater quantity and quality that cover and embed environmental and socioeconomic aspects of groundwater sustainability and guide governance and management actions. The AHP has been used to assign weights of the selected criteria and sub criteria; based on their relative importance to the main goal. Those weights were then compared with each other in a pair-wise matrix; the Eigen values and consistency ratio were calculated to validate the assigned weights of the selected parameters. The ranges of these parameters were classed and rated then reclassified with GIS for the application of the sustainability index in pilot area (El-Khatatba area).

The present work and the applied approach introduces a development of groundwater sustainability index that may be followed and can be modified by other criteria selected, features included and /or weight assigned.

\section{THE STUDY AREA}

The study area is a part of the western Nile Delta fringes. This area is limited by latitudes $30^{\circ} 0^{\prime}-30^{\circ}$ $15^{\prime} \mathrm{N}$ and longitudes $30^{\circ} 30^{\prime}-30^{\circ} 31^{\prime} \mathrm{E}$. It is bounded by El Rayah El Naseri from the east and Cairo - Alex. Desert road from the west, Fig.(1). The study area is geomorphologically distinguished into one unit ; the alluvial plains which is classified into young alluvial plains ( nearly flat representing the main cultivated lands parallel to the River Nile) and the old alluvial plains that stretch to the west of the young alluvial plain till Cairo Alex. Road. The water resource in the study area combines both surface water and groundwater. The surface waters are represented by Rosetta branch that discharge Nile water to the studied area through El-Rayah El-Naseiry canal. On the other hand, the groundwater occupies two water-bearing formations: Quaternary aquifer (mainly composed of sands, gravel with clay lenses) and Miocene aquifer (composed from sandstones with clay interbeds). A hydrogeological cross section of the study area is shown in Fig. (2).

Although ElKhatatba area lies on the western part of Nile Delta aquifer, it has a limited water resource; as a results of the increment in reclamation projects. Farmers are suffering from shortage of surface water and groundwater forced to depend on the groundwater abstraction from wells. To avoid the deterioration of the aquifer system in this area an efficient integrated and sustainable management plan for water resources needed.
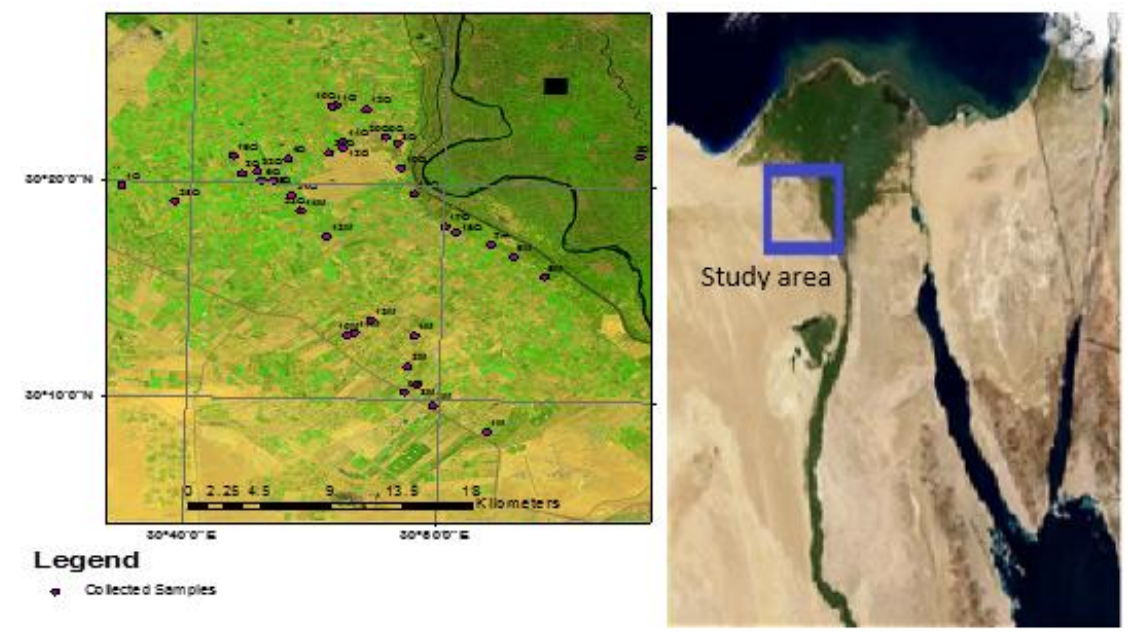

Fig1. Location map of the study area with the collected groundwater samples 


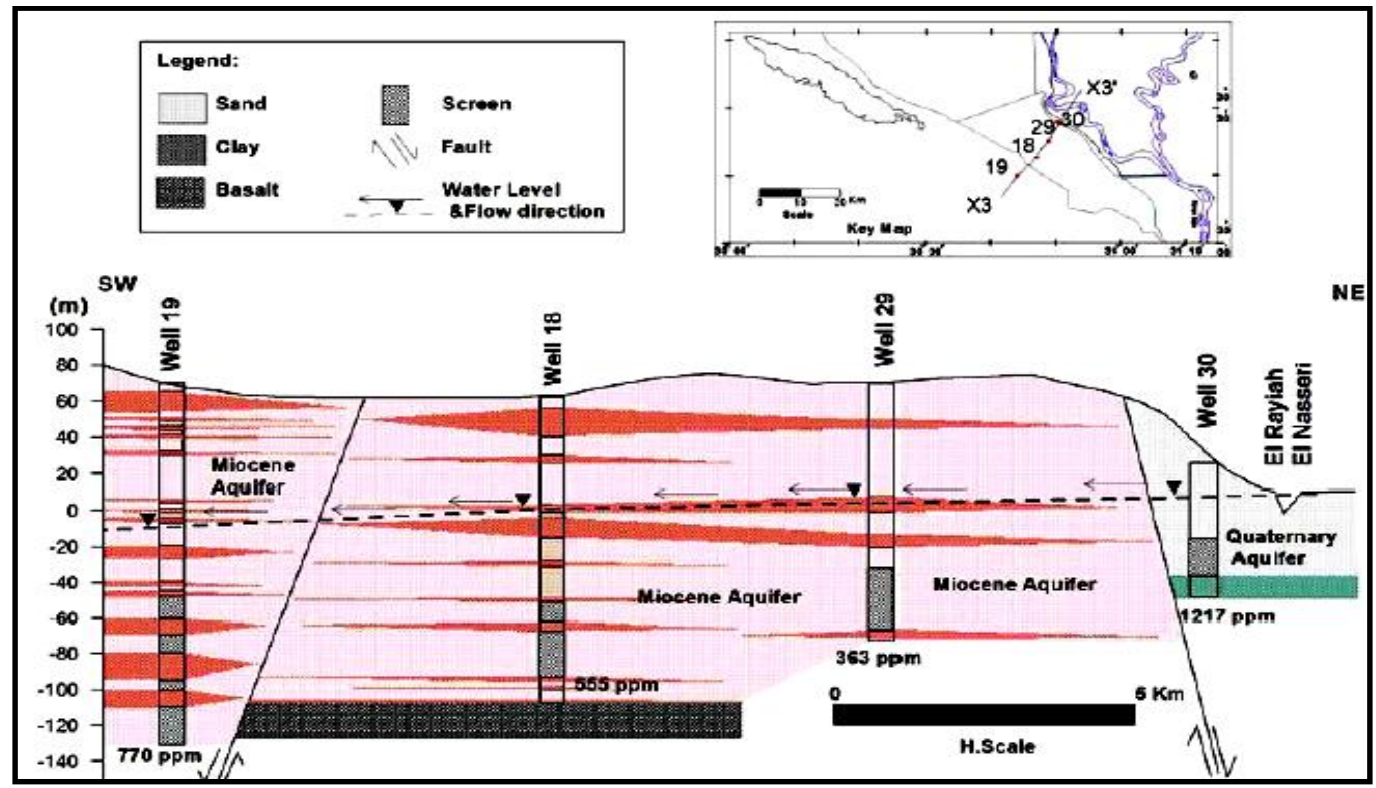

Fig2. Hydrogeological cross section across Quaternary and Miocene aquifer (El Gamal, 2005).

\section{Materials ANd MethodS}

The present work is devoted mainly to develop an index for groundwater sustainability and to apply it in a pilot area. The work combined both field, lab and office activities integrated to propose the index and to get more insights on the hydrochemical and hydrogeological factors controlling the sustainability of the groundwater resource in the pilot area. The methods applied and the procedures followed summarized as follow:

\subsection{Development of the Groundwater Sustainability Index}

The Analytical Hierachy Process (AHP), (Saaty, 1980) which is one of the widely used Multi Critera Dicision Analysis (MCDA) tools has been used to develop a measure index for Groundwater Sustainability in this work (GSI). This has been performed as follow.

Five factors are believed to influence and control groundwater sustainability have been selected. The selected parameters were assigned weights based on their relative importance to groundwater sustainability, according to Saaty approach; all factors and sub-criteria are compared in a pairwise comparison matrix and their relative normalized weight (W) were then calculated. To control and test the consistency of the assigned weights, consistency Ratio (CR) less than 10\% (as recommended by Saaty technique) has been reached and accordingly the calculated weights become acceptable. The verified weights and rates of the criteria and sub-criteria are used to calculate numerical values for the groundwater sustainability index according to the following equation

\section{Groundwater Sustainability Index=}

\section{$\sum$ ( weight of alternatives of each creteria $x$ importance of cretira}

The range of values of the index can be categorized into sustainability classes.

\subsection{Application of the New Environmentally Sustainability Index on a Pilot area}

The hydrogeological and hydrochemical conditions of the study area have been characterized, the thematic geospatial maps of the sustainability criteria have been prepared and the developed index applied on them, as follow.

\section{(A) Hydrochemical and hydrogeological characterization of the pilot area}

The hydrogeological conditions of the study area have been inventoried from literatures, surveyed in the field and presented in this work. Groundwater sampling and ionic / isotopic measurements were conducted to determine the hydrochemical conditions.

Thirty-eight groundwater samples were collected from the two main aquifers (Quaternary and Miocene), samples locations, Fig. (1) Ground surface elevation were recorded using a Global Positioning System (GPS) manufactured by GARMIN. pH, Electrical Conductivity (EC), and Total 
Dissolved Solids (TDS) were measured in the field. The water samples have been laboratory analyzed for major ions and stable isotopes (O18 and D) in the Central Laboratory of Isotope Hydrology, Egyptian Nuclear and Radiological Regulatory Authority (ENNRA). The analysis of major ions were carried out according the methods described in ASTM (2017). All parameters are expressed in milligrams per liter. Data quality was assessed using the charge balance between the difference of cations and anions (expressed in meq/l) divided by their summation which was always $< \pm 5 \%$. Environmental Stable isotope $\left(\delta^{18} \mathrm{O}\right.$ in \%o) were measured using Picarro Laser Spectroscopy in the Central Laboratory of Environmental isotope hydrology, ENRRA.

\section{(B) Data acquisition, thematic layers development and sustainability index applying}

The indicators required to measure the groundwater sustainability in the study area have been extracted and mapped using the data of hydrogeological and hydrochemical characterization. These criteria and associating features have been assigned weightage and scores and converted to raster format using spatial analyst, extension of ArcGIS software. These thematic layers were finally integrated using overlay analysis and groundwater prospective potentiality zones of the study area were demarcated; the main processes include reclassification of individual layers by integrating reclassified layers using weighted overlay analysis technique that is guided by AHP-pairwise comparison matrix using ARCGIS 10.3.

\section{RESULTS AND DiSCUSSION}

\subsection{Groundwater Sustainability Index (GSI) Development}

\subsubsection{Selection of Sustainability Indicators}

Indicators are key parameters for constitution of the groundwater sustainability index. These should combine both quantitative and qualitative metrics to ensure the protection of the resources against depletion as well as contamination. The quantitative and qualitative dimensions of the index have been strictly considered in the selection of the indicators in this work, this is because they have a big role in the economic and environmental sustainability and social well-being. The indicators selected in this work take into consideration the wide variety of indicators available in literature and the goals to reflect the groundwater availability, supply, demand, quality and vulnerability in integrative term. The five proposed indicators combine Change in Water level, Renewability of Groundwater, and Aquifer Thickness (in the quantitative dimension), Water Quality Index and Vulnerability Index (in the qualitative dimension). These indicators are justified as being Appropriate and measurable, relevant and integrative, predictable and sensitive to time and space.

\subsubsection{Weight Pairwise Marix, Normalized Weights and Consistence}

The thematic layers of the five factors which are believed to influence and control groundwater sustainability have been processed for development of the groundwater sustainability index. A pairwise comparison matrix was constructed based on the five input sustainability criteria, (Table 1). Each entry of the matrix represents the influence of the rowfactor relative to the column-factor. The factor influences on each other based on Saaty's one-to-nine point scale, (Saaty, 1980).

Table1. Comparison matrix and priority vector for sustainability criteria.

\begin{tabular}{|l|l|l|l|l|l|}
\hline Criteria & $\begin{array}{l}\text { Change in } \\
\text { Head }\end{array}$ & $\begin{array}{l}\text { Saturated } \\
\text { Thickness }\end{array}$ & Renewability & Quality & Vulnerability \\
\hline $\begin{array}{l}\text { Change in } \\
\text { Head }\end{array}$ & 1 & 3 & 3 & 5 & 8 \\
\hline $\begin{array}{l}\text { Saturated } \\
\text { Thickness }\end{array}$ & 0.33 & 1 & 1 & 3 & 6 \\
\hline Renewability & 0.33 & 1 & 1 & 3 & 6 \\
\hline Quality & 0.2 & 0.33 & 0.33 & 1 & 4 \\
\hline Vulnerability & 0.12 & 0.17 & 0.17 & 0.25 & 1 \\
\hline CR=0.035 &
\end{tabular}

The relative weights for each of the criteria and sub-criteria of decision hierarchy were determined. Eigenvector and logarithmic methods are commonly used for deriving relative weights (Saaty, 1991), where, the corresponding weights of decision elements are determined by comparing the normalized eigenvalue to the principal eigenvalue. 
A Novel Groundwater Sustainability Index using AHP/GIS Approach

Table2. Comparison matrix of Change in Head sub-criteria.

\begin{tabular}{|l|l|l|l|}
\hline Change in Head Range $(\mathrm{m})$ & $>1$ & 0 & $<1$ \\
\hline$>1$ & 1 & 3 & 7 \\
\hline 0 & 0.333 & 1 & 5 \\
\hline$<1$ & 0.143 & 0.2 & 1 \\
\hline $\mathbf{C R}=\mathbf{0 . 0 6 8}$ &
\end{tabular}

Table3. Comparison matrix of Renewability of the water resources sub-criteria.

\begin{tabular}{|c|c|c|c|c|c|}
\hline $\begin{array}{l}\text { Renewability } \\
\text { Range }(\%)\end{array}$ & $0-20$ & $20-40$ & $40-60$ & $60-80$ & $80-100$ \\
\hline $0-20$ & 1 & 0.5 & 0.2 & 0.143 & 0.111 \\
\hline $20-40$ & 2 & 1 & 0.25 & 0.167 & 0.125 \\
\hline $40-60$ & 5 & 4 & 1 & 0.333 & 0.2 \\
\hline $60-80$ & 7 & 6 & 3 & 1 & 0.333 \\
\hline $80-100$ & 9 & 8 & 5 & 3 & 1 \\
\hline
\end{tabular}

Table4. Comparison matrix of Saturated thickness sub-criteria.

\begin{tabular}{|c|c|c|c|c|c|}
\hline $\begin{array}{l}\text { Saturated } \\
\text { thickness } \\
\text { (m) }\end{array}$ & $<10$ & $10-50$ & $50-100$ & $100-150$ & $>200$ \\
\hline$<10$ & 1 & 0.333 & 0.2 & 0.1437 & 0.1113 \\
\hline $10-50$ & 3 & 1 & 0.333 & 0.2 & 0.143 \\
\hline $50-100$ & 5 & 3 & 1 & 0.3333 & 0.2 \\
\hline $100-150$ & 7 & 5 & 3 & 1 & 0.333 \\
\hline$>200$ & 9 & 7 & 5 & 3 & 1 \\
\hline & \multicolumn{5}{|c|}{$\mathrm{CR}=\mathbf{0 . 0 5 3}$} \\
\hline
\end{tabular}

Table5. Comparison matrix of Quality of the groundwater sub-criteria.

\begin{tabular}{|c|c|c|c|c|c|}
\hline $\begin{array}{c}\text { Quality of } \\
\text { Groundwater }\end{array}$ & Excellent & Good & Poor & Bad & Unfit \\
\hline Excellent & 1 & 3 & 7 & 8 & 9 \\
\hline Good & 0.333 & 1 & 5 & 6 & 7 \\
\hline poor & 0.143 & 0.2 & 1 & 2 & 3 \\
\hline Bad & 0.125 & 0.167 & 0.5 & 1 & 2 \\
\hline Unfit & 0.111 & 0.143 & 0.333 & 0.5 & 1 \\
\hline CR $\mathbf{0 . 0 4 1}$
\end{tabular}

Table6. Comparison matrix of Vulnerability to pollution of the sub-criteria.

\begin{tabular}{|l|r|r|r|r|}
\hline $\begin{array}{l}\text { Vulnerability to } \\
\text { pollution }\end{array}$ & Low & Moderate & High & V.High \\
\hline Low & 1 & 3 & 7 & 9 \\
\hline Moderate & 0.333 & 1 & 5 & 3 \\
\hline High & 0.143 & 0.2 & 1 & 1 \\
\hline V.High & 0.111 & 0.143 & 0.333 & \\
\hline CR= 0.06 & \multicolumn{3}{|r|}{} \\
\hline
\end{tabular}

Checking the consistency level of the previous judgment step is mandatory in which, optimal decision-making in pairwise comparison is mainly associated with the permissible value of consistency ratio of the main criteria $(C R=0.035)$ suggesting no revision in the pairwise comparison of the main criteria, (Saaty and Vargas, 1991). The pairwise comparison matrices of sub criteria (rating values of each sub-criteria in each criteria were established also, and the relative normalized weight (W) were then calculated, as shown in Table 3. Consistency of pairwise comparison matrix (CR) was calculated to be $0.068,0.05,0.053,0.041$, and 0.06 for change in head, renewability, saturated thickness, quality and vulnerability, respectively. Hence, the weight criteria within the criteria were quite consistent and no need for further reevaluation processes, $(\mathrm{CR}<0.1)$. Table $(7)$ represents the overall rating and weighting of criteria and sub criteria of the developed index. And this index will be applied on the pilot area (ElKhatatba area). 
Table7. Overall ratings of sustainability index.

\begin{tabular}{|c|c|c|c|c|c|}
\hline $\begin{array}{l}\text { Go } \\
\text { al }\end{array}$ & Categories & $\begin{array}{c}\text { Effective weight of } \\
\text { criteria }\end{array}$ & $\begin{array}{c}\text { Sub- } \\
\text { Categories }\end{array}$ & $\begin{array}{c}\text { Effective weight of sub- } \\
\text { criteria }\end{array}$ & $\begin{array}{c}\text { Alternati } \\
\text { ve }\end{array}$ \\
\hline \multirow{22}{*}{ 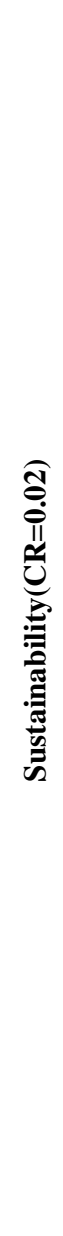 } & \multirow{3}{*}{ Change in Head(m) } & \multirow{3}{*}{0.469} & $>0$ & 0.649 & 0.251 \\
\hline & & & 0 & 0.279 & 0.135 \\
\hline & & & $<1$ & 0.072 & 0.040 \\
\hline & \multirow{5}{*}{ Renewability (\%) } & \multirow{5}{*}{0.203} & $0-20$ & 0.03 & 0.006 \\
\hline & & & $20-40$ & 0.05 & 0.010 \\
\hline & & & $40-60$ & 0.134 & 0.027 \\
\hline & & & $60-80$ & 0.265 & 0.054 \\
\hline & & & $80-100$ & 0.516 & 0.105 \\
\hline & \multirow{5}{*}{ Saturated Thickness (m) } & \multirow{5}{*}{0.203} & $<10$ & 0.033 & 0.007 \\
\hline & & & Oct-50 & 0.063 & 0.013 \\
\hline & & & $50-100$ & 0.129 & 0.026 \\
\hline & & & $100-150$ & 0.262 & 0.053 \\
\hline & & & $>200$ & 0.513 & 0.104 \\
\hline & \multirow{5}{*}{ Quality Index(Qi) } & \multirow{5}{*}{0.09} & $<50$ & 0.535 & 0.048 \\
\hline & & & $50-100$ & 0.287 & 0.026 \\
\hline & & & $100-200$ & 0.085 & 0.008 \\
\hline & & & $200-300$ & 0.055 & 0.005 \\
\hline & & & $>300$ & 0.037 & 0.003 \\
\hline & \multirow{4}{*}{$\begin{array}{l}\text { Vulnerability Index } \\
\text { (DRASTIC) }\end{array}$} & \multirow{4}{*}{0.036} & Low & 0.583 & 0.021 \\
\hline & & & Moderate & 0.29 & 0.010 \\
\hline & & & High & 0.085 & 0.003 \\
\hline & & & V.High & 0.042 & 0.002 \\
\hline
\end{tabular}

\subsection{Application of the developed index}

\subsubsection{Hydrochemical and Hydrogeological characteristics of the Study Area.}

Hydrogeologically, the groundwater occurs in two aquifers in the study area. The Quaternary aquifer occupies the major part of the studied area, it is composed of fluviatile graded sand and gravel intercalated with thin clay lenses and mainly recharged from the Nile water, infiltration of irrigation water and from the adjacent canals. The discharge from this aquifer takes place both naturally or artificially. On the other hand, the Miocene aquifer is represented by the Moghra Formation, and mainly composed of sand, sandstone and clay interbeds with vertebrate remains and silicified wood. The recharge of the Miocene aquifer takes place from the Quaternary aquifer in the southeastern part of the studied area, the other sources of recharge to the Miocene aquifer are the occasional rain storms and the upward leakage from the deep Nubian sandstone aquifer, so that the water of the Miocene aquifer is considered as a mixture of paleowater and recent water.

Hydrochemically, the results of ionic and isotopic analysis of thirty eight groundwater and surface water samples collected in this work Table (8) have been used to characterize the hydrochemical conditions of the study area and to prepare the water quality and renewability thematic maps.

Table8. statistical analyses of hydrochemical and isotopic results of the collected groundwater samples.

\begin{tabular}{|c|c|c|c|c|c|c|c|c|c|c|c|c|}
\hline Item & $\mathbf{p H}$ & $\begin{array}{c}\mathbf{N a} \\
(\mathbf{m g} / \mathbf{l})\end{array}$ & $\begin{array}{c}\mathbf{T D S} \\
(\mathbf{m g} / \mathbf{l})\end{array}$ & $\begin{array}{c}\mathbf{K} \\
(\mathbf{m g} / \mathbf{l})\end{array}$ & $\begin{array}{c}\mathbf{M g} \\
(\mathbf{m g} / \mathbf{l})\end{array}$ & $\begin{array}{c}\mathbf{C a} \\
(\mathbf{m g} / \mathbf{l})\end{array}$ & $\begin{array}{c}\mathbf{H C O}_{3} \\
(\mathbf{m g} / \mathbf{l})\end{array}$ & $\begin{array}{c}\mathbf{S O}_{4} \\
(\mathbf{m g} / \mathbf{l})\end{array}$ & $\begin{array}{c}\mathbf{C l} \\
(\mathbf{m g} / \mathbf{l})\end{array}$ & $\begin{array}{c}\mathbf{N O}_{3} \\
(\mathbf{m g} / \mathbf{l})\end{array}$ & $\begin{array}{c}\boldsymbol{\delta}^{\mathbf{1 8}} \\
(\mathbf{\%})\end{array}$ \\
\hline Aquifer & \multicolumn{10}{|c|}{ Quaternary } \\
\hline Mean & 7.97 & 670.70 & 106.68 & 7.22 & 25.44 & 66.61 & 180.42 & 88.16 & 196.18 & 5.47 & 0.72 \\
\hline St.Dev. & 0.28 & 679.80 & 171.43 & 2.69 & 20.32 & 65.95 & 54.35 & 74.62 & 379.71 & 7.13 & 1.10 \\
\hline Kurtosis & -0.78 & 18.26 & 18.92 & 5.29 & 10.78 & 13.72 & 9.65 & 2.60 & 20.69 & 15.47 & 1.10 \\
\hline
\end{tabular}


A Novel Groundwater Sustainability Index using AHP/GIS Approach

\begin{tabular}{|c|c|c|c|c|c|c|c|c|c|c|c|}
\hline Skewness & 0.21 & 4.05 & 4.18 & 1.94 & 2.88 & 3.34 & 2.47 & 1.78 & 4.40 & 3.63 & 1.38 \\
\hline Range & 1.02 & 3412.60 & 852.00 & 12.40 & 102.14 & 330.00 & 301.65 & 272.38 & 1919.50 & 36.33 & 3.30 \\
\hline Min. & 7.50 & 305.80 & 29.00 & 4.20 & 4.86 & 15.00 & 90.85 & 23.02 & 25.50 & 0.00 & -0.38 \\
\hline Max. & 8.52 & 3718.40 & 881.00 & 16.60 & 107.00 & 345.00 & 392.50 & 295.40 & 1945.00 & 36.33 & 2.92 \\
\hline Aquifer & \multicolumn{10}{|c|}{ Miocene } \\
\hline Mean & 7.96 & 742.57 & 145.11 & 6.79 & 23.88 & 56.24 & 211.59 & 105.82 & 205.82 & 7.84 & 0.15 \\
\hline St.Dev. & 0.21 & 715.58 & 177.70 & 4.71 & 21.39 & 71.96 & 58.45 & 116.00 & 406.23 & 10.07 & 1.75 \\
\hline Kurtosis & 1.99 & 16.74 & 16.41 & 4.95 & 12.07 & 14.08 & 4.24 & 3.91 & 19.20 & 1.92 & -1.14 \\
\hline Skewness & 0.40 & 3.92 & 3.85 & 2.33 & 3.12 & 3.51 & 1.19 & 2.09 & 4.30 & 1.57 & 0.67 \\
\hline Min. & 7.50 & 299.90 & 29.00 & 3.20 & 4.20 & 10.00 & 90.85 & 15.00 & 25.50 & 0.00 & -1.93 \\
\hline Max. & 8.52 & 3718.40 & 881.00 & 20.00 & 107.00 & 345.00 & 392.50 & 420.00 & 1945.00 & 36.33 & 2.92 \\
\hline
\end{tabular}

The variation in the TDS values in the groundwater samples reflects the limited variation of the recharge conditions and salinization processes. Based on the classification of freshness of water (Davis and De Wiest 1966); about (95\%) of the studied groundwater samples are fresh water, the rest are of brackish nature (>1000 mg/l). Five hypothetical salt assemblages that represent the combination between cations and anions under prevailing geochemical conditions in the study area are dedusce. The appearance of $\mathbf{N a C l}, \mathrm{Na}_{2} \mathrm{SO}_{4}, \mathrm{NaHCO}_{3}, \mathbf{M g}\left(\mathrm{HCO}_{3}\right)_{2}, \mathbf{C a}\left(\mathrm{HCO}_{3}\right)_{2}$ in $38 \%$ of Quaternary and $77 \%$ of the Miocene sample, is an indication of fresh water meteoric character that is slightly modified by leaching and cation exchange. The two combinations $\left(\mathrm{NaCl}, \mathrm{Na}_{2} \mathrm{SO}_{4}, \mathrm{MgSO}_{4}, \mathrm{CaSO}_{4}\right.$, $\left.\mathrm{Ca}\left(\mathrm{HCO}_{3}\right)_{2}\right)$ and $\left(\mathrm{NaCl}, \mathrm{NaSO}_{4}, \mathrm{MgSO}_{4}, \mathrm{Mg}\left(\mathrm{HCO}_{3}\right)_{2}, \mathrm{Ca}\left(\mathrm{HCO}_{3}\right)_{2}\right)$ appear in the salt composition of about $17 \%$ of the Quaternary aquifer samples, $12 \%$ of the Miocene aquifer samples; revealing the mixing character that could be developed under the effects of dissolution of evaporates, as well as, leachates of sulphates rich fertilizers, accordingly the salts $\left(\mathrm{MgSO}_{4}, \mathrm{CaSO}_{4}, \mathrm{Mg}\left(\mathrm{HCO}_{3}\right)_{2}, \mathrm{Ca}\right.$ $\left.\left(\mathrm{HCO}_{3}\right)_{2}\right)$ are formed. Two salts combinations of marine character and advanced stage of development; $\left(\mathrm{NaCl}, \mathrm{MgCl}_{2}, \mathrm{MgSO}_{4}, \mathrm{CaSO}_{4}, \mathrm{Ca}\left(\mathrm{HCO}_{3}\right)_{2}\right)$ and $\left(\mathrm{NaCl}, \mathrm{MgCl}_{2}, \mathrm{CaCl}_{2}, \mathrm{CaSO}_{4}, \mathrm{Ca}\right.$ $\left.\left(\mathbf{H C O}_{3}\right)_{2}\right)$ appear in about $11 \%$ of the Miocene groundwater samples and $42 \%$ of the Quaternary groundwater samples. These appear in the areas of over exploitation that leads to seepage of old water through lineaments also at Alexandria / Cairo road.

The salts composition varies in Quaternary than the Miocene where salinization processes are higher and more effective under the natural and/or anthropogenic factors.

\subsubsection{Sustainability of ElKhatatba area}

The five sustainability criteria of the study area have been prepared and the developed index applied on them as follow:

\section{1-Change in Head.}

The hydraulic head generally decreases and groundwater flows from east to west. The values of head changes with time as a result of exploitation/ recharge relation. A map has been constructed for change in head between 1960 and 2020, (Salem and Dina, 2016 and Ibrahem, 2020). The values of water level changes were mapped rated and reclassified according to proposed AHP normalized weight as shown in Fig. (4a).

\section{2-Renewability of the groundwater.}

The isotopic content (oxygen-18 and deuterium) of the groundwater in the study area was used to map the groundwater renewability as the percentage of Nile water component to paleowater component in the sampled wells, Table (2). The geographical distribution of $\delta^{18} \mathrm{O}$ in both the Quaternary and Miocene aquifers show a systematic change with distance from the Rayah el Nasry canal (branch of Nile) where the most enriched isotopic contents are present in the eastern part of the two aquifers close to it, reflecting that the Nile water is the main source of recharge at these localities particularly in North and South El-Khatatba area. The wells that lie far from the Nile become progressively depleted in $\delta^{18} \mathrm{O}$ for both the two aquifers, reflecting lower contribution of the recent Nile water on account of other isotopically depleted source of recharge, Fig.(3).

The following isotopic mixing equation has been used to calculate the contribution of recent recharge from Nile water to the sampled wells, (percentage contribution from Nile water $=1$ - percentage 
contribution of old water). The values calculated for Nile water percentage were mapped rated and reclassified according to proposed AHP normalized weight as shown in Fig. (4b).

$\frac{Q \text { old }}{Q \text { Total }}=\frac{(\delta 180 \text { Total }-\delta 180 \mathrm{New})}{((\delta 180 \text { old }-\delta 180 \mathrm{New}))} \ldots \ldots \ldots \ldots$

Where $\mathrm{Q}_{\text {old }} / \mathrm{Q}_{\text {Total }}$ is the contribution of Nubian aquifer water in the collected groundwater samples, $\delta^{18} \mathrm{O}_{\text {Total }}$ is the content of $\delta^{18} \mathrm{O}$ in the collected sample, $\delta^{18} \mathrm{O}_{\text {old }}$ is the value of the $\delta^{18} \mathrm{O}$ content in the Nubian Sandstone (-10) and $\delta^{18} \mathrm{O}_{\text {New }}$ is the value of the $\delta^{18} \mathrm{O}$ content in the Nile water (3).

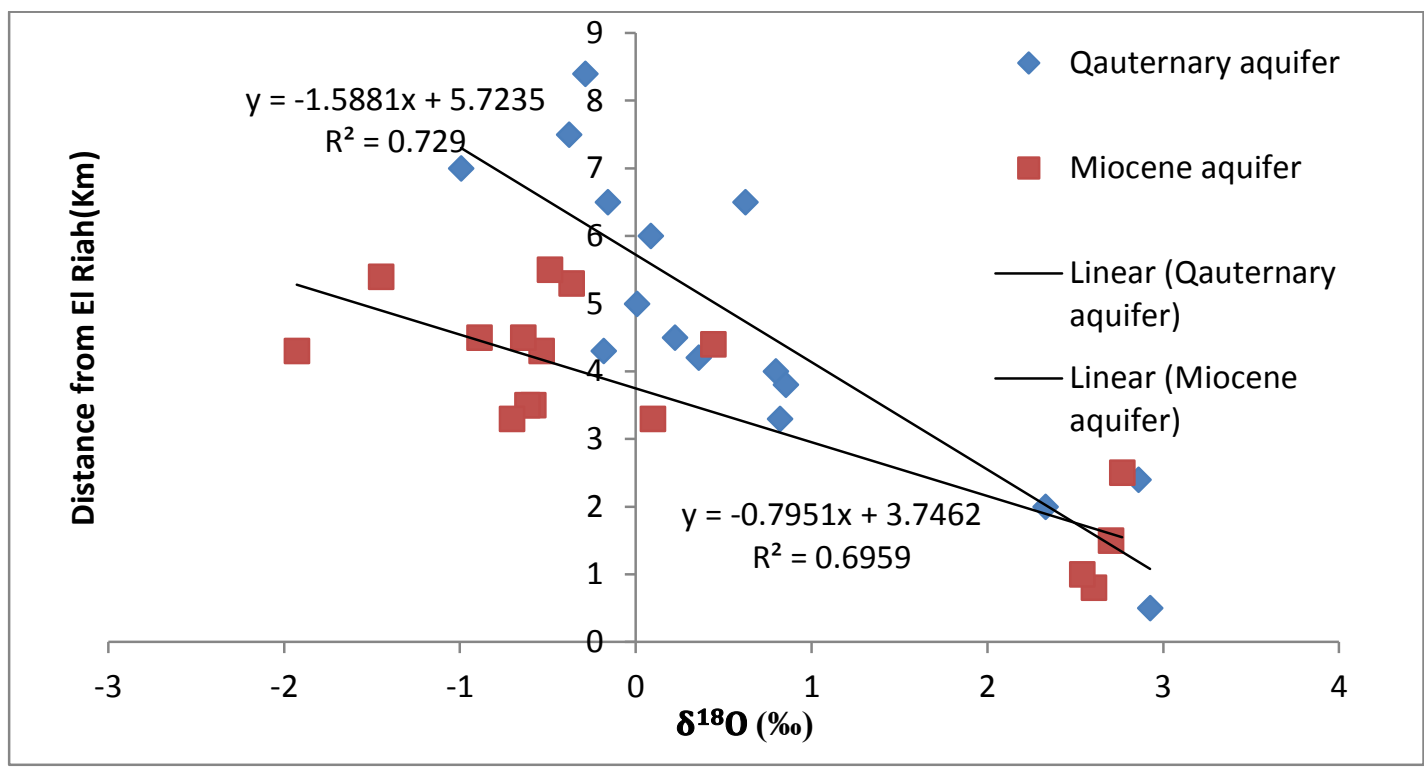

Fig3. Variation of $\delta^{18} \mathrm{O}$ with distance from El-Rayah El Nasery for Quaternary and Miocene aquifer.

\section{1-Saturated thickness}

The saturated thickness of the two main bearing formations (Quaternary and Miocene) in the study area ranges from $60 \mathrm{~m}$ at the north and increase to $115 \mathrm{~m}$ at the south of the study area, Fig. (4d).

\section{2-Groundwater Quality of the study area}

The groundwater quality evaluation for the human drinking is based mainly on the TDS values and the concentration of major and minor ions in comparison with the recommended limits given in the standards for the different uses. Water quality index (WQI) is valuable and unique rating to depict the overall water quality status in a single term that is helpful for the sustainability studies. Water quality index for drinking and domestic uses have been calculated according to equation (2) for A set of seven water quality parameters (Total Dissolved Solid (TDS), Chloride, Sulphate, Calcium, Magnesium, Sodium, and Total Hardness), (Table 4), the quailty rating scale for each parameter $\boldsymbol{q} \boldsymbol{i}$ was calculated using the following equation (3) according to (Rown et al. 1972).

$W Q I=\frac{\sum q \mathbf{w i} \mathbf{i}}{\sum \mathbf{W i}} \ldots \ldots \ldots \ldots$

$q i=100 * \frac{V n}{V s} \ldots \ldots . .$.

where $\boldsymbol{V}_{\boldsymbol{n}}$ is the actual value of the sample and $\boldsymbol{V} \boldsymbol{s}$ is the standard value which had been selected according to the Egyptian Higher committee of Water guidelines (1995).

Table9. some selected standard value (Egyptian Higher committee of Water guidelines, 1995) and their corresponding unit weights.

\begin{tabular}{|l|l|l|l|}
\hline Chemical Constituent & Max. permissible limit in $\mathbf{~ g / / ~}$ & $\mathbf{1 / v s}$ & Wi \\
\hline Calcium & 200 & 0.00500 & 0.033028 \\
\hline Chloride & 500 & 0.00200 & 0.013211 \\
\hline Hardness as $\mathbf{C a C O}_{3}$ & 500 & 0.00200 & 0.013211 \\
\hline Magnesium & 150 & 0.00670 & 0.044037 \\
\hline
\end{tabular}




\begin{tabular}{|l|l|l|l|}
\hline \multicolumn{2}{|c|}{} & 0.00083 & 0.005505 \\
\hline Sodium & 1200 & 0.005 & 0.033028 \\
\hline Sulphate & 200 & 0.0025 & 0.016514 \\
\hline pH & 400 & 0.12738854 & 0.841468 \\
\hline
\end{tabular}

WQI of the collected samples ranged from 35 to 100 revealing the variation of quality status from excellent to good according to Rown scale (Rown et al. 1972), the map of water quality results has been constructed and reclassified according to proposed weight of AHP, the weighted map is shown in Fig.(4d).

\section{Vulnerability to pollution}

The assessment of groundwater vulnerability is important and useful for mitigation of groundwater pollution. The DRASTIC vulnerability index (Aller, 1987). has been applied in this work, as indicator for sustainability. The values of the seven parameters for the different wells are extracted from literature (Ibrahim, 2005, El-Gamal, 2005, and Reda, 2007). Ranges and ratings for the parameters were applied according to (Aller, 1987). The areas of high vulnerability (high DRASTIC index) were found in the north and southern part of the study area, while the areas located at western part of the study area were with relatively low vulnerability risk. The values of groundwater vulnerabilities were mapped rated and reclassified according to proposed AHP normalized weight as shown in Fig. (4e).

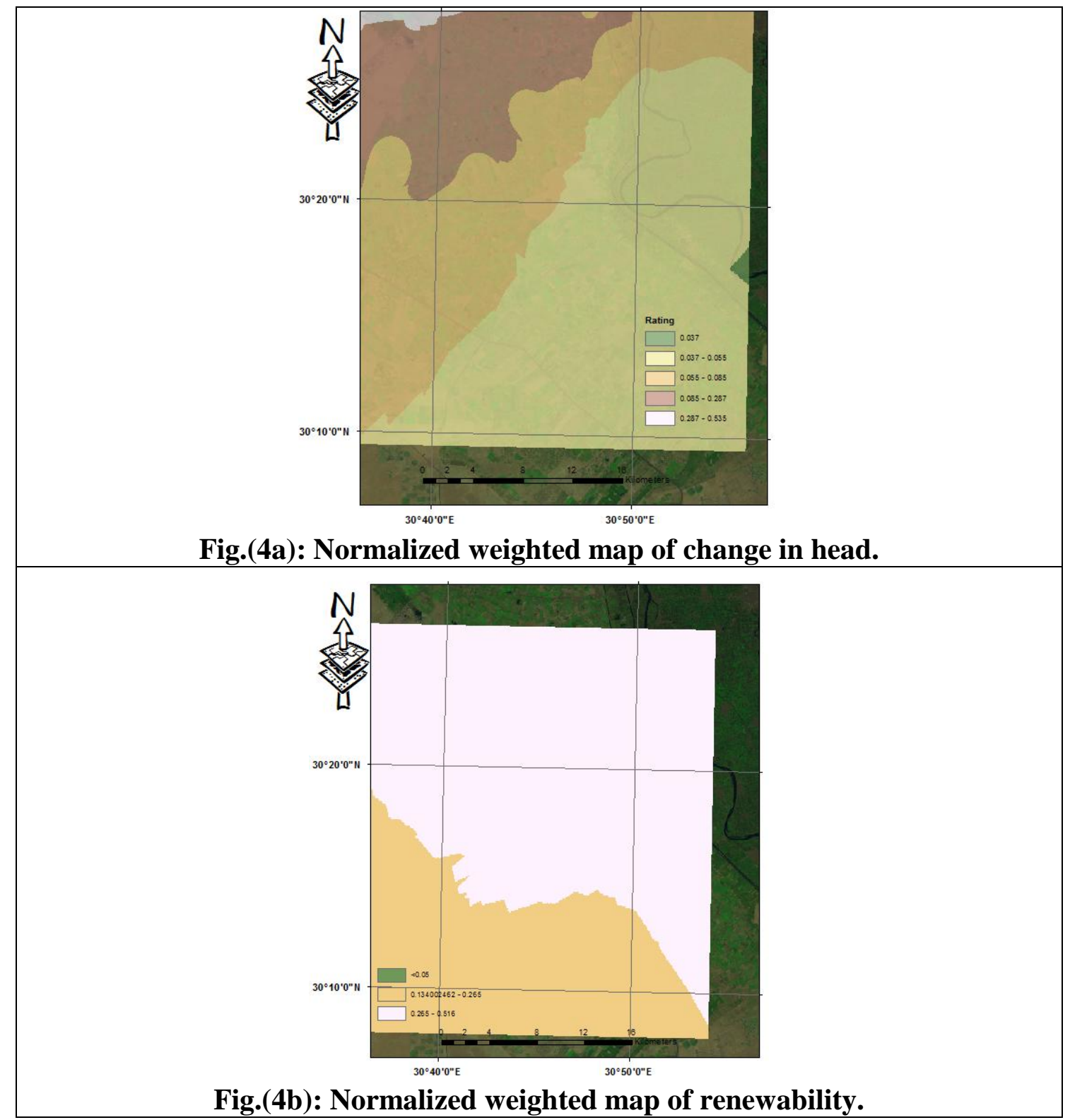




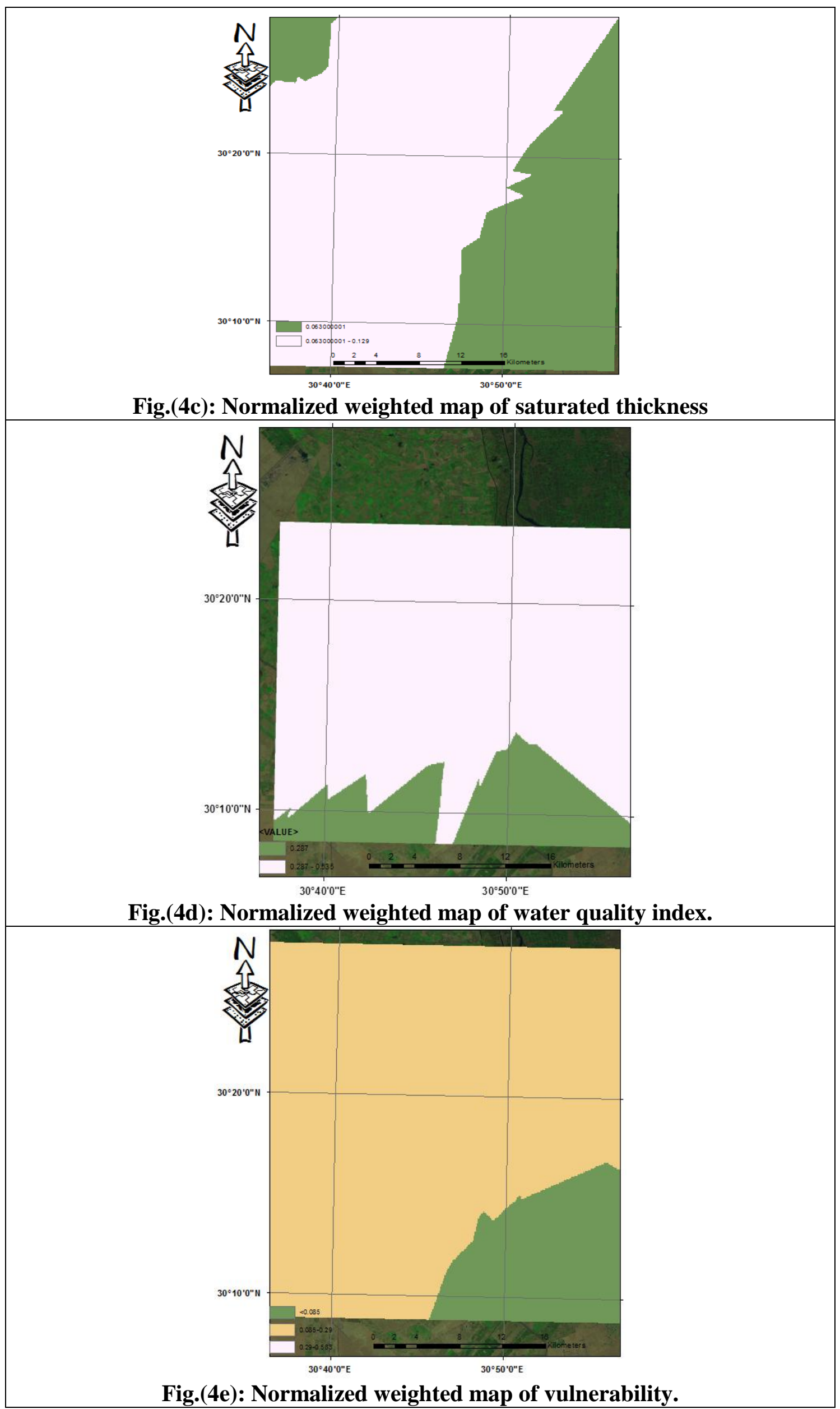




\section{Final Sustainability Map}

The reclassified layers of change in head, renewability, saturated thickness, water quality and vulnerability and their corresponding percentage influence on sustainability index were integrated to produce a sustainability index map using weighted overlay tool of ArcGIS 10.3 software. The produced sustainability map of the study area is classified into two classes; low and medium zones based on the final (weights * rate) summation. Based on the sustainability map of the study area, shown in Fig. (5); the least sustainability zone are lying at the southern eastern zone of El-Khatatba especially at Cairo-Alex. Desert road, which seems to be corelatable with the rapid increment in reclamation projects in this area, as well as, private farms that stressed the aquifer at those localities, hence they are far from the surface water system replenishment. On the other hand, the zones near the Nile branch are more sustainable; which might be attributed to the continuous recharge from the surface water to the surrounding area so replenishment factor play a vital role in this area except at some sporadic localities, where the abstraction exceed the replenishment of the water as seen in some northern sector.

Based on the results of this work, further management regulation should be constrained and prescribed by governorate for controlling the groundwater extraction and suggestion of new techniques in irrigation, especially at lower sustainability zones to prevent further deterioration in the groundwater study area.

\section{Validation of the index}

The land-use and change detection maps show great usefulness evidence and indicator in planning of groundwater management and development. In this work land use and its change with time (Ammeish et al, 2016), have been used as a validation tool for the proposed sustainability index. It is obviously noticed that a lot of changes observed in groundwater development along the cultivated areas especially in ElKhatatba Road in sector (A) that has a sustainability index value greater than that obtained in South Khatatba and areas around Cairo-Alex Desert road in sector (B) which has lower sustainability index value, Fig.(4). Accordingly, it is advisably to focus on the area that has a rapid increment in agriculture development for detailed assessment, to evaluate the impact of these rapid changes on groundwater aquifer.

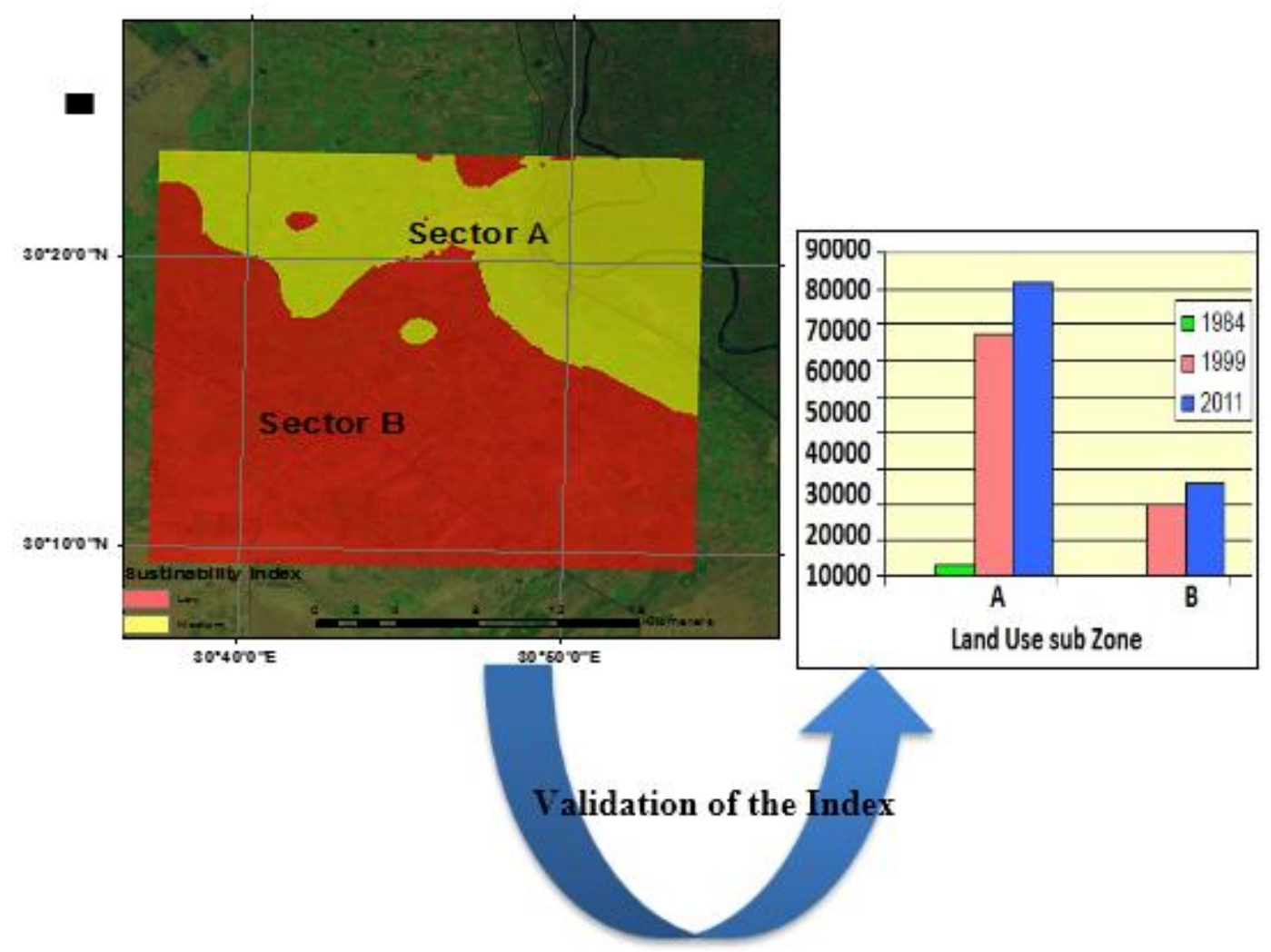

Fig5. Sustainability index of ElKhatatba area with emphasis on Land use change with time (Ammeish et al, 2016) as verification tool. 


\section{CONCLUSION}

The present work helps to provide a measurable single-score groundwater sustainability index for ElKhatatba area. It considers in an integrative term both the quantitative and qualitative factors that reflect the socioeconomic and environmental conditions of the groundwater system (Change in Water level, Renewability of Groundwater, Aquifer Saturated Thickness, Water Quality and Vulnerability Indexes). The overall sustainability of groundwater resources in the El Khatatba area vary between moderate (about $40 \%$ of the study area) for northern and eastern sectors near surface water to low grades (about 60\% of the study area) for southern parts and near Cairo Alex.Desert road. The sustainability situation of the groundwater in the study area highlights the necessity for continuous monitoring and better governance and management of the groundwater resources. The present work and the applied approach AHP/MPDA is an early stage of development groundwater sustainability index, it may be followed and can be modified by criteria selected, features included and /or weight assigned. The method have been validated using the change in land use with time in the pilot area.

\section{REFERENCES}

[1] Sadek M.\& Hagagg K. , (2020), Impact of reduced flow on 137Cs behavior in Ismailia Canal and surrounding groundwater systems, Environmental Science and Pollution Research.

[2] https://doi.org/10.1007/s11356-020-10242-z.

[3] Alley, W.M., Reily, T.E., Franke, O.L., (1999) Sustainability of Ground-Water Resources. U.S. Geological Survey Circular 1186, Denver, CO.

[4] Glesson T., Cuthbert M., Ferguson G., Perrone D, (2020), Global groundwater sustainability resources, and systems in the Anthropocene, Annual review of earth and planetary sciences, Vol.48:431:463

[5] Saaty, T.L. (1980), The Analytic Hierarchy Process; McGraw-Hill: New York, NY, USA.

[6] Davis, S. N., and De Wiest, R.J.M., 1966. Hydrogeology, John Willy and Sons, Inc. New York.

[7] Egyptian Higher Committee for water (1995), Egyptian standards for drinking water and domestic uses, Cairo, Egypt, 124pp,.

[8] Ibrahim, S. M., (2000) Groundwater hydrology of El Khatatba area and its vicinities, West Nile Delta, Egypt. M.Sc. thesis, Faculty of engineering, Ain Shams University, Egypt

[9] El-Gamal, H. (2005), Environmental tracers in groundwater as tools to study hydrological questions in arid regions. Ph.D. Thesis Combined Faculties of the Natural Sciences and for Mathematics of the Ruperto Carola University of Heidelberg, Germany.

[10] Reda M.A., (2007) Hydrogeochemical study for groundwater for the west-northern area of Wadi El-Natron -Western desert, Egypt. M.Sc. Thesis, faculty of Science, Minufia University. Egypt.

[11] Aller, L., Bennet, T., Lehr, J.H. and Petty, R.J., DRASTIC, (1987): a standardized system for evaluating groundwater pollution potential using hydrogeological settings. US-Environmental Protection Agency.

[12] Ammeish E.S., Mabrouk., B. M and Morsy W.S. ( 2016): RS and GIS Based Approach for Detecting Landuse Changes and its Impact on the Groundwater Aquifer, Life Science Journal;13(4)

[13] Awang, A.; Ghani, A.T.A.; Abdullah, L.; Ahmad, M.F. (2017), Global Weights of Coastal Erosion Risk indicators using AHP Method: A Case Study of Setiu Wetlands. Natl. Symp. Math. Sci., 24, 050014.

[14] Abadi, L.S.K.; Shamsai, A.; Goharnejad, H. (2015), An Analysis of the Sustainability of Basin Water Resources using Vensim Model. KSCE J. Civ. Eng., 19, 1941-1949.

[15] Sun, S.K.; Wang, Y.B.; Liu, J.; Cai, H.J.; Wu, P.T.; Geng, Q.L.; Xu, L.J., (2016), Sustainability assessment of regional water resources under the DPSIR framework. J. Hydrol., 532, 140-148.

[16] Saaty T. L. and Vargas L. G. (1991), De Logic of Priorities, RWS Publications, Pittsburgh, PA, USA.

[17] Standards Methods for Examination of water and wastewater (2017), American Public Health Association, American Water Works Association Pollution Control Federation, Washington, D. C.

[18] Ibrahem S. M. M. (2020) Groundwater hydrology and characteristics of the tertiary aquifers, Northwest Cairo, Egypt, NRIAG Journal of Astronomy and Geophysics, 9:1, 420-432.

[19] https://doi.org/10.1080/20909977.2020.1751924

[20] Salem Z. E. and El-Bayumy D. A.,(2016). Hydrogeological, petrophysical and hydrogeochemical characteristics of the groundwater aquifers east of Wadi El-Natrun, Egypt. NRIAG Journal of Astronomy and Geophysics (2016) 5, 124-146.

[21] Juwana, I., Perera, B.J.C., Muttil, N., (2009). Conceptual framework for the development of West Java water sustainability index. In: Anderssen, R.S., Braddock. 
[22] De Carvalho, S.C.P., Carden, K.J., Armitage, N.P., (2009). Application of a sustainability index for integrated urban water management in Southern African cities: case study comparison

[23] Chaves, H.M.L., Alipaz, S., ( 2007). An integrated indicator based on basin hydrology, environment, life, and policy: the watershed sustainability index. Water Resources Management 21 (5), 883-895.

[24] Policy Research Initiative, (2007). Canadian water sustainability index. PRI Project Report on Sustainable Development, February.

[25] Shaban, E. (2000), Environmental impacts of development on the hydrogeology and hydrochemistry on the Western Nile Delta, Ph.D. Thesis, Faculty of Science, Cairo University, Egypt.

[26] Standards Methods for Examination of water and wastewater (2017), American Public Health Association, American Water Works Association Pollution Control Federation, Washington, D. C.

[27] Abd Allah, H.,F., I., (2016) Sustainable development of groundwater resources in the area between AbuRoash-El Khatatba, Southwest Nile delta, Egypt. Ph.D. Minufia University, Faculty of science.

[28] Rown, R.M, McCleiland, N.J., Deiniger, R.A. and O'Connor, M.F.A. ( (1972); Water quality index crossing the physical barrier", (Jenkis, S.H. ed.) Proceedings in International Conference on water pollution Research Jerusalem 6. 787-797.

Citation: K.Hagagg \& M.Sadek " A Novel Groundwater Sustainability Index using AHP/GIS Approach", International Journal of Research in Environmental Science (IJRES), vol. 6, no. 4, pp. 28-40, 2020. Available: DOI: http://dx.doi.org/ 10.20431 /2454-9444.0604003

Copyright: (c) 2020 Authors. This is an open-access article distributed under the terms of the Creative Commons Attribution License, which permits unrestricted use, distribution, and reproduction in any medium, provided the original author and source are credited. 